\title{
ВИЛОНОВУВАННЯ АНТИРЕЛІГІЙНОЇ ПРОПАГАНДИ В ОНТОЛОГІЇ РАДЯНСЬКОГО (1917-1921 рр.)
}

\begin{abstract}
Основна ідея статті: антирелігійна та антицерковна політика унормовувалась та регламентувалась партійно-державним апаратом задля досягнення гомогенності та уніфікачії суспільства. Сутнісно ия політика на інтерпретаційному, пропагандистському, діяльнісному рівнях відповідала онтологї радянського.

Основною метою дослідження є увиразнення ролі антирелігійної та антицерковної пропаганди в системі державно-церковних відносин 1917-1921 років та окреслення іманентних характеристик иих складників більшовицької влади в онтології радянського.

Характер, зміст, форми і методи антирелігійної пропаганди, підпорядковуючись головній меті витісненню релігії та церкви з усіх сфер суспільного буття, визначалися комуністичною партією з огляду на зміни соціально-економічної і політичної ситуації в країні.

Фактично від початку 1920-х років маніфестування політичних иілей у галузі релігії та хаотичне втручання радянської адміністрачії у церковні справи поступово трансформувалося у широкомасштабний наступ влади на релігію та церкву.
\end{abstract}

Ключові слова: релігія, церква, суспільство, держава, менталітет, ідентичність, радянськість.

orcid.org/0000-0003-4375-5350 Doctor of Historical Sciences, Professor, Director of the State Scientific Institution «Encyclopedic Publishing House»

(Ukraine, Kyiv) akyrydon@ukr.net

\section{ORIGIN OF ANTI-RELIGIOUS PROPAGANDA IN THE ONTOLOGY OF THE SOVIET (1917-1921)}

The main idea of the article: Anti-religious and anti-church policy was standardized and regulated by the partystate apparatus in order to achieve homogeneity and unification of society. In essence, this policy at the interpretive, propaganda, activity levels corresponded to the Soviet ontology.

The main purpose of the study is to clarify the role of anti-religious and anti-church propaganda in the system of state-church relations of 1917-1921 and to outline the immanent characteristics of these components of Bolshevik power in the Soviet ontology.

The peculiarities of the development of anti-religious propaganda in Ukraine were the relatively belated (in relation to the RSFSR) beginning of its implementation, namely - from 1920; the need to take into account the national factor; the diversity of the religious-church movement of the 1920s; features of the social and class structure of society, etc.

The nature, content, forms and methods of anti-religious propaganda, subject to the main goal - the expulsion of religion and the church from all spheres of social life, were determined by the Communist Party in view of changes in socio-economic and political situation in the country.

Gradually (in our opinion, in the second half of the 1920s) a kind of system of anti-religious propaganda was formed, which was a combination of several components:

- ideological (ideological-theoretical) guidelines, provisions, decisions, which determined the features and relevant goals, objectives and direction of anti-religious propaganda for a particular period;

- organizational measures aimed at achieving certain objectives; 
- forms and methods of work taking into account the stated goals and features of the stages of the historical period of development (for example, the new economic policy, industrialization, collectivization, etc.).

Despite the declaration, the party-state leadership did not have a clear awareness of the content, forms and content of anti-religious propaganda in the early 1920s (probably until the middle of the decade). It is worth paying attention at least to the use of the terms "anti-religious propaganda", "anti-church propaganda", "fight against religious prejudices (atheism)", etc. The issue of periodization of the development of anti-religious propaganda needs further study, although the first attempts in this direction were made by contemporaries in the 1920s and 1930s.

In fact, from the beginning of 1920, the manifestation of political goals in the field of religion and the chaotic interference of the Soviet administration in church affairs gradually transformed into a large-scale attack by the authorities on religion and the church.

Key words: religion, church, society, state, mentality, identity, Sovietness.

Постановка проблеми. Утвердження радянської влади потребувало засадничої перебудови всіх складників суспільної організації та утвердження відповідних світоглядних пріоритетів, нової комуністичної моралі. 3-поміж іншого, йшлося про утвердження більшовицької моделі державно-церковних відносин, сфокусоване на досягненні головної стратегічної цілі - подолання релігії та релігійного світогляду в усіх їх проявах, а відтак - знищення будьяких релігійних організацій та церкви як суспільного інституту. Для досягнення визначеної мети партійно-державним функціонерам потрібно було віднайти засоби, які б, по-перше, уможливили б усунення з суспільного життя такого могутнього інституту, яким тривалі роки був уособленням «спільності почуття» - церкву; по-друге, які б пропагували як комуністичні ідеали на перспективу, так і найближчі завдання партії; по-третє, впроваджували атеїзацію настроїв суспільства; по-четверте, сприяли нав'язуванню комуністичних світоглядних орієнтирів і цінностей та формуванню «нової» людини. Таким чином, 3 утвердженням більшовицької державно-політичної системи не трансцендентна ідея Бога, а соціальна утопія комунізму повинна була слугувати саме знакомсимволом «спільності почуття» або «божественного соціального» (Durkheim, 1968: 3).

Мета статті. Основною метою дослідження $\epsilon$ увиразнення ролі антирелігійної та антицерковної пропаганди в системі державно-церковних відносин 1917-1921 років та окреслення іманентних характеристик цих складників більшовицької влади в онтології радянського. Для реалізації цієї мети необхідно вирішити низку завдань: визначити зміст і сутність поняттєвокатегоріального інструментарію; оприсутнити характер антирелігійної та 
антицерковної пропаганди періоду 1917-1921 років; проаналізувати засоби/механізми втілення антирелігійної та антицерковної політики більшовицького режиму. Задекларована тема грунтується на поєднанні кількох сегментів: державно-церковні відносини, утвердження комуністичної ідеології, формування ціннісно-смислових орієнтирів суспільства тощо. Увазі читача пропонується перша стаття запланованого авторкою циклу статей задекларованої проблеми з подальшим розширенням хронологічного діапазону дослідження.

Базова теза авторської концепції полягає у взаємообумовленості та взаємозалежності суспільних явищ та характеру, змісту й механізмів втілення політичного режиму в конкретно-часовому вимірі. Антирелігійна політика була одним із механізмів конструювання нової культурної парадигми та утвердження нової ідентичності - ідентичності радянської.

Гіпотеза дослідження: антирелігійна та антицерковна політика унормовувалась та регламентувалась партійно-державним апаратом задля досягнення гомогенності та уніфікації суспільства. Сутнісно ця політика на інтерпретаційному, пропагандистському, діяльнісному рівнях відповідала онтології радянського. Для підтвердження викладеного, апелюємо до міркувань М. Бердяєва: «Непримиренно вороже ставлення комунізму до будь-якої релігії не $є$ явище випадкове, воно належить до самої сутності комуністичного світогляду. Комуністичний лад є крайнім етатизмом, у ньому держава постає тоталітарною, абсолютною, він вимагає примусової єдності думки» (Бердяев, $1990: 129)$.

Аналіз досліджень. Палітру сучасного вітчизняного історіографічного дискурсу задекларованої проблеми здебільшого з маркуванням хронологічного діапазону 1920-1930-х років репрезентовано в дослідженнях Л. Бабенко, В. Вериги， Л. Дудки， Т. Євсєєвої， О. Ігнатуші， В. Калабської， А. Киридон, М. Костіва, О. Мальцевої, О. Нестулі, В. Пащенка, В. Силантьєва, Г. Славути, О. Топчій, О. Тригуба, Б. Хіхлача, В. Циби, О. Чучаліна та ін. 
Виклад основного матеріалу. Вдамося до аналізу понятійнокатегоріального апарату дослідження. Термін «радянське», «радянськість» використовуємо на означення змісту процесів та явищ, притаманних суспільнополітичному ладу 3 утвердженням більшовицького режиму. Йдеться про систему ідеологічних, політичних, економічних, культурно-духовних інструментів / чинників, що цілеспрямовано формували / конструювали ціннісно-смислові пріоритети суспільства, характерологічні риси світобачення, відповідні оцінні конотації та ідеологеми, соціальні переживання тощо та мали оприявнювати творення «нової людини» й репрезентувати соціалістичну дійсність. Задля втілення «радянськості», партійно-державне керівництво серед важелів впливу вдавалось до маніпулювання суспільною свідомістю та настроями, втілюючи комуністичну ідеологію.

Під «ідеологією» розуміємо систему політичних переконань та цінностей, орієнтованих на певні шляхи завоювання влади (з використанням сукупності всіх можливих засобів досягнення визначеної мети), окреслення відповідей на протиріччя суспільного життя, формування матриці колективної свідомості, увиразнення символів тощо. Вона «наводить мости між реальним і бажаним станом справ, гарантуючи виконання соціальних ролей, від яких в іншому випадку відмовилися б через відчай або апатію» (Гірц, 2001 : 241). Американський антрополог К. Гірц трактував ідеології як «схематичні образи соціального порядку» (Гірц, 2001 : 256), «карти соціальної реальності і матриці колективної свідомості» (Гірц, 2001 : 259). Змістово йдеться про «систему символів» і «структуру смислів, які взаємодіють між собою» (Гірц , 2001 : 243).

Вагома роль в ідеологічному курсі держави належала антирелігійній політиці, вістря якої спрямовувалось проти релігії (антирелігійна пропаганда) та церкви (антицерковна пропаганда) задля утвердження атеїстичного світогляду, мінімізації, а згодом - поступового викорінення / витіснення релігії 3 життя суспільства.

Антирелігійна пропаганда є формою ідеологічної боротьби, спрямованої на витіснення релігії з усіх сфер суспільного буття. Ця ідеологічно вмотивована 
діяльність мала здійснювати вплив на свідомісно-когнітивному рівні задля формування певних переконань, поглядів, поведінки тощо. В умовах комуністично-радянського режиму антирелігійна пропаганда виконувала цілком конкретну роль в системі тоталітарної індокринації. Вона була однією 3 форм антирелігійної політики та засобом утвердження комуністичного світогляду, моралі, обрядовості. Суттєві характеристики будь-якого соціуму увиразнюються в його менталітеті. Менталітет є певною своєрідною пам’яттю людини про минуле, психологічна детермінанта поведінки людей, які вірні своєму історично ментальному «коду» за будь-яких обставин, не виключаючи й катастрофічні. В менталітеті суспільства віддзеркалюється, певним чином, історичний досвід нації, перипетії їі формування й розвитку. Глибинно-психічні установки, тобто безперервно «працюючі» поза полем «відкритої» чи зовнішньої (так званої «чистої») свідомості духовні орієнтири думки й волі, містять сприйняття, оцінку й поведінку. В основі роботи «ментальних механізмів» увиразнюється три основні функціональні установки: установка сприйняття (когнітивний елемент), установка оцінки (афект), установка поведінки (діяльнісний компонент «тріади», що розглядається), які можуть бути структуровані в своєрідну глибинно-психічну «вертикаль» (Полєжаєв, $2015: 72)$.

Антицерковна пропаганда - одна 3 форм антирелігійної політики, суголосна антирелігійній пропаганді, спрямована на боротьбу проти релігійних інституцій.

Релігійний чинник був одним із маркерів ментальних основ суспільства фактично до бурхливих подій початку ХХ ст. : традиційно саме релігія давала суспільству досить впорядковану картину світу, вносячи в людське життя узгодженість і визначаючи іï місце в світі. В умовах розколотого внаслідок війни та революційних потрясінь суспільства ще рельєфніше поставала потреба світоглядних орієнтацій. 3 руйнуванням усталеної структури суспільства i втратою колись єдиних морально-ціннісних орієнтирів абсолютно не 
випадковим видається сприйняття частиною суспільства нової світоглядної системи, запропонованої більшовицькою партією.

Аналізуючи «швидкість» перемоги більшовиків та марксистської ідеології у протиборстві з релігією, слід врахувати, що визрівання передумов цих процесів відбувалося в попередні роки. Уже в другій половині XIX ст. спостерігається розчарування в православній церкві і наростання релігійної апатії в аристократичному середовищі, поширення атеїстичних поглядів серед інтелігенції, яка переживала своєрідну релігійну кризу (Хейер, 2002 : 25). Ідейний монополізм православного християнства був підточений не тільки внутрішнім розбратом в ній, а й поширенням ідей лібералізму, марксизму, ніцшеанства та націоналізму. «Скрізь була певна кількість явних або, частіше, більш чи менш потаємних безвірників і байдужих, але серед загального складу нації вони становили меншість, - зауважував С. Аверинцев. - Віра мас «відчутно холонула», але вона трималася, трималася хоча б за інерцією». Відбувалась зміна смислових орієнтирів: те, що раніше вважалося втіленням духовної сили, несподівано ставало навпаки лише «неясно окресленим i побіжним» (Аверинцев, 2004 : 360). Уже в роки революції збліднув міф про глибоку релігійність народу і відданість його православ’ю. I власне Церква (духовенство), і держава (більшовики) фактично постали перед необхідністю обрання орієнтирів та визначення ролі і місця в подальшому існуванні. Але якщо церква сподівалася на повернення свого колишнього статусу та авторитету в системі державно-церковних відносин, то влада мала намір витіснити колишню головну ідеологічну інституцію 3 ii соціокультурної ніші, знищивши «старих» богів i проголосивши «нову» релігію. За цими процесами стояли не якісь абстрактні структури. Учасниками або (щонайменше) свідками подій були конкретні люди, яких виховувала сама дійсність. Не випадково, суспільство виявилося розколотим: частина виступила в обороні православної віри й свого права їі сповідувати. Інша ж частина, і (як свідчить розвиток подій) не менша, виявила, навпаки, бажання нищити й руйнувати все, пов’язане з церквою, зрікаючись віри. 
Метою комуністичного режиму, заснованого на диктатурі правлячої партії, було поступове обмеження, витіснення, а в перспективі викорінення релігії. Головна мета антирелігійної пропаганди полягала саме в утвердженні комуністичного і витісненні релігійного світогляду. «Справа комуністичної партії, - наголошувалося в одному 3 комуністичних документів, - шляхом антирелігійної пропаганди вести боротьбу за знищення всякої релігії і всякої церкви, поєднуючи антирелігійну пропаганду з діями пролетарської держави» (ЦДАГО України. Ф. 1. Оп. 20. Спр. 1168. Арк. 93).

Фактичне проведення антирелігійної пропаганди було гарантоване Декретом про відокремлення церкви від держави і школи від церкви, згодом законодавчо закріпленим у республіканських Конституціях, зокрема i в Конституції Української СРР. Основним партійним документом, який визначав зміст і напрямки антирелігійної пропаганди в перші роки радянської влади, була Програма РКП(б), прийнята на VIII з’їзді партії в 1919 році. Зокрема, пункт 13-й Програми наголошував, що партія не задовольняється вже декретованим відокремленням церкви від держави і школи від церкви, а прагне «до нового зруйнування зв'язку між експлуататорськими класами i організацією релігійної пропаганди, сприяючи фактичному звільненню трудящих мас від релігійних забобонів і організовуючи найширшу науковоосвітню та антирелігійну пропаганду» (Восьмий з'їзд РКП(б), 1979:48). Вимоги партійної програми в подальшому були конкретизовані в ряді рішень з'їздів, постанов пленумів, директив ЦК РКП(б) і ЦК КП(б)У. Однак, вважаємо за потрібне підкреслити той факт, що, попри проведення певних заходів, перший обіжник ЦК РКП(б), який стосувався безпосередньо антирелігійної пропаганди, з часу появи Програми РКП(б) 1919 року, за твердженням О. Ярославського, 3’явився лише в 1921 році (Ярославский, 1929 : 6), що, на нашу думку, також впливало на перебіг подій післяреволюційного часу.

Антирелігійна пропаганда 1917-1920 років була складником загальнополітичної пропаганди та агітації, що спрямовувалися на роз'яснення положень Декрету про відокремлення церкви від держави і школи від церкви, 
на викриття «класової сутності релігії», «класових позицій реакційного духовенства» та його «контрреволюційної діяльності» тощо (Персиц, 1967 : 1537; Плаксин, 1968; Лгушина, 1965). Головним же завданням на цьому історичному етапі партійно-державне керівництво вважало відрив якомога більшої кількості віруючих від церкви, послаблення авторитету останньої і іiі служителів, створення «образу ворога».

Серед найпоширеніших форм і методів антирелігійної пропаганди тих років переважали суто агітаційні форми: листівки, плакати, мітинги, диспути. У серпні 1918 року на засіданні колегії Наркомосу А. Луначарський наголосив: «Ми не повинні допускати можливості церкві розігрувати мученицьку роль, ... наш безперервний наступ на неї повинен вестися в культурній площині. Цю боротьбу слід вести у формі диспутів, статей i брошур») (Народное просвещение, $1918: 7)$.

В ухвалі травневого (1918 року) пленуму ЦК РКП(б) намічалося «повести проти духовенства рішучу письмову агітацію», вагома роль в якій відводилася листівкам і плакатам. Про важливість цієї ділянки роботи свідчить телеграма В. Леніна до Пензенського виконкому (серпень 1918 року), в якій наголошувалося на неприпустимості скорочення тиражу листівок з посиланням на нестачу грошей: «Ми не пошкодуємо сотні тисяч на агітацію» (Ленин: 149). Антирелігійні плакати Д. Моора, В. Дені, М. Черемних та інших виразними засобами й відвертою антирелігійною спрямованістю мали «викривати» священників, «духовну сивуху» церкви тощо. Письмова агітація передбачала також видання антирелігійних брошур і статей. У 1918-1920 роках було видано понад 30 найменувань таких публікацій (Дурдыневский, Берцианский, 1925: 180-181).

3 лютого 1919 року став виходити журнал «Революция и церковь» (протягом двох років побачили світ 12 номерів). Фактично це було єдине періодичне видання антирелігійного характеру. Однак, наклад його був незначним, і через брак паперу і палива часопис виходив нерегулярно (1920 
року надрукували тільки одну книгу (№9-12), а в 1921 році видання з'явилося лише у вигляді невеликої друкованої стінгазети (Воронцов, 1973 : 26).

У першому номері журналу в статті А. Луначарського «Про антирелігійну пропаганду» одним із методів іiі впровадження визначалося популярне роз'яснення проблем природознавства в історії (Луначарский, 1919:8). У той же час більшовики вперше застосували як метод боротьби з релігією антицерковну кампанію, пов’язану з «розкриттям молей». Уперше використали й такий засіб пропаганди як кіно (Воронцов, 1973 : 33-35). Показово, що, одержавши від П. Красікова під час засідання Раднаркому 12 квітня 1919 року повідомлення про наявність кінострічки про розкриття мощей в Троїце-Сергієвій лаврі, В. Ленін написав доручення секретарю: «Треба прослідкувати і перевірити, щоб пошвидше показали це кіно по всій Москві» (Ленин: 279).

Побіжно зауважимо, що вже на початковому етапі антирелігійна пропаганда розглядалася як засіб атеїзації мас. У цьому контексті, усвідомлюючи особливий переважаючий вплив релігії на жіноцтво, партія більшовиків як одне з головних завдань визначила залучення останніх до активного політичного і господарського життя. У вересні 1919 року ЦК РКП(б) ухвалив рішення про створення відділів по роботі серед жінок при губернських, міських, районних і волосних народних комітетах. При ЦК РКП(б) теж було створено такий відділ.

Усвідомлюючи необхідність формування «нової людини», тактику боротьби з релігією в школі перших років революції більшовики зводили до того, щоб ні в якому разі не допускати релігію в навчальний процес. Тому йшлося не про антирелігійне, а швидше про безрелігійне виховання (Амосов, 1932 : 285-286). Згодом у Кодексі законів про народну освіту, затвердженому ВУЦВК 1 листопада 1922 року) буде зафіксовано: «3 метою визволення працюючих мас від релігійних забобонів, всі учбово-виховуючі наукові i політико-просвітні установи розвивають широку i планомірну науковопросвітню та антирелігійну пропаганду». На цій підставі голова Полтавського Окрвиконкому в інструктивному листі до всіх райвиконкомів, сільрад, 
завідуючих установами соціального і професійного виховання і працівників освіти округи наголошував: «...Все виховання й освіта в установах учбововиховуючих повинні бути вільними від будь-якого релігійного впливу» (ДАПО. Ф. Р. 363. Оп. 1. Спр. 35. Арк. 1-1зв.).

Але непевність становища новостверджуваної радянської системи i «відволікання іншими завданнями, набагато важливішими в той час на інших фронтах», за твердженням О.Ярославського, відсунули антирелігійну роботу «на останнє місце», хоча для іiі ведення все ж «вдалось тоді виділити деякі сили» (Ярославский, 1929 : 15-16). Цей початковий період розвитку антирелігійної пропаганди голова Центральної ради Спілки войовничих безвірників назвав періодом «бурі i натиску», підкреслюючи переважно політичний характер боротьби 3 церквою за всіма напрямами» (Ярославский, $1932: 323)$.

В Україні вищезазначений початковий етап становлення антирелігійної пропаганди мав переважно опосередкований вплив і прояви, що зумовлювалося розвитком подій національно-визвольних змагань 1917-1920 років і кількаразовим утвердженням радянської влади.

Один із активних провідників антирелігійного фронту зазначав: «Нам на Україні майже безпосередньо довелося розпочати боротьбу проти церковності, обрядовості і релігійності 3 другого ступеня пропаганди, 3 роботи над створенням нової науки і моралі. Ми майже не знаємо періоду безпосередньої фізичної боротьби $з$ церквою». Далі автор пояснює: «Великоросійський тип контрреволюційного священника, який би відкрито очолював змову проти Радянської влади і закінчував своє життя під ударами червоноармійського багнету, чужий Україні. Хвилі державних переворотів, приливи й відливи комунізму обезбарвили й принизили духовенство» (Рожицын, 1922 : 6).

Загальне керівництво агітаційно-пропагандистською i культурнопросвітницькою роботою в республіці на початку 1920-х років покладалося на агітаційно-пропагандистські відділи (агітпропи). Агітпроп ЦК КП(б)У, головним завданням якого визначалося «ідейне виховання населення в дусі 
комунізму», було створено згідно $з$ рішенням Політбюро ЦК українських комуністів 31 жовтня 1920 року. Очолив відділ М. Попов (ЦДАГО України. Ф. 1. Оп. 6. Спр. 748. Арк. 1). Про характер діяльності агітпропу ЦК можна скласти уяву за переліком циркулярів, виданих відділом хоча б протягом грудня 1920 - листопада 1921 року (ЦДАГО України. Ф. 1. Оп. 20. Спр. 7. Арк. 97, 118). На місцях агітаційно-пропагандистські відділи створювалися при партійних комітетах усіх рівнів, а при військових комісаріатах діяли політикопросвітні відділи. В Харківській губернії агітпропи стали створюватися ще в січні 1920 року і в середині місяця вже діяли при губкомі партії, а також у 6-8 повітових комітетах КП(б)У (Силантьев, 1998 : 102-103). Співпрацюючи 3 місцевими органами радянської влади, агітпропи проводили агітаційну i культурно-просвітницьку роботу, стежили за настроями населення, організовували партійні осередки, відкривали клуби і хати-читальні.

Після Х з’їзду РКП(б) (березень 1921 року) структура апарату партійних губкомів, у тому числі й агітпропи, була реорганізована. Натомість виникли політвідділи усної агітації і пропаганди, партійної освіти, друкованої агітації і пропаганди. Агітпропи губкомів здійснювали керівництво роботою районних і повітових агітпропів і губполітпросвіт (ЦДАГО України. Ф. 1. Оп. 20. Спр. 748. Арк. 216). Губкомам КП(б)У пропонувалося «розгорнути найширшу антирелігійну пропаганду, ряд лекцій і доповідей з історії і критики релігії» (ЦДАГО України. Ф. 1. Оп. 20. Спр. 748. Арк. 42). Обіжник ЦК КП(б)У, Агітпропу і Головполітосвіти від 10 червня 1921 року «Про антирелігійну пропаганду», підкреслюючи «важливість і невідкладність завдань пропаганди комунізму», необхідність боротьби «з релігійними забобонами, з культурною контрреволюцією, 3 церковним обскурантизмом (затемненням умів), 3 релігійними пережитками, в ім'я комуністичної культури і революційної класової вільної свідомості трудящих». Визначалось, що антирелігійна пропаганда повинна проводитися апаратами політосвіт під безпосереднім керівництвом агітпропвідділів парткомів. При цьому для проведення роботи залучалися підвідділи політосвіт: політагітації (лекційна секція), наукової 
пропаганди i худсектору. Кожен губполітос мав виокремити одного відповідального комуніста, якому доручалося вивчати і збирати матеріали про поширення релігійно-містичних рухів та здійснення керівництва антирелігійною пропагандою в губернії. Водночас обіжник визначав конкретні заходи та форми проведення антирелігійної пропаганди, серед котрих називалися влаштування диспутів на релігійні теми, організація пропагандистських кампаній, лекцій, бесід, читань, видання відповідних брошур, плакатів, листівок, організація виставок і музеїв, постановка п’єс антирелігійного спрямування в театрах тощо.

Центральним Комітетом більшовицької партії наголошувалося на важливості поширення антирелігійної роботи серед жінок. Особливий акцент робився на необхідності пропаганди наукового світогляду шляхом поширення природознавства та збільшення годин у школах партійного і радянського будівництва на вивчення питань релігії. Крім організаційних заходів, названий обіжник визначав і суто практичні кроки: «Необхідно використати боротьбу, що відбувається зараз в Україні між українською і російською православною церквами, для обережного, але неухильного і послідовного викриття сутності будь-яких віросповідань і будь-якої церкви як засобу експлуатації» (ЦДАГО України. Ф. 1. Оп. 20. Спр. 748. Арк. 56-58).

3 середини 1921 року спостерігалися спроби налагодження систематичного і планомірного проведення антирелігійної пропаганди. 3 цією метою агітпроп ЦК вимагав від губкомів надсилати звіти про проведення антирелігійної пропаганди (двічі на місяць) і всі відповідні матеріали з місць(ЦДАГО України. Ф. 1. Оп. 20. Спр. 748 : Арк. 72; Спр. 749. Арк. 56). Вимагалося також беззаперечно виконувати всім структурним ланкам вимоги обіжників Наркомюсту, Наркомосу і Наркомзему щодо релігії і церкви (ЦДАГО України. Ф. 1. Оп. 20. Спр. 748. Арк. 160). Особливу роль у проведенні антирелігійних заходів відводилося «відповідальним партійним товаришам» (Циркулярное письмо, 1922 : 188-189; ЦДАГО України. Ф. 1. Оп. 20. Спр. 748. Арк. 175). 
Висновки. Таким чином, особливості розвитку антирелігійної пропаганди в Україні були зумовлені відносно запізнілим (стосовно РСФРР) початком іiі реалізації, а саме - з 1920 року; необхідністю врахування національного чинника; строкатістю релігійно-церковного руху 1920-х років; особливостями соціально-класової структури суспільства та ін.

Характер, зміст, форми і методи антирелігійної пропаганди, підпорядковуючись головній меті - витісненню релігії та церкви 3 усіх сфер суспільного буття, визначалися комуністичною партією з огляду на зміни соціально-економічної і політичної ситуації в країні. Поступово (на нашу думку, в другій половині 1920-х років) сформувалася своєрідна система антирелігійної пропаганди, яка становила сукупність кількох складників:

ідеологічні (ідейно-теоретичні) настанови, положення, рішення, котрі визначали особливості й відповідні цілі, завдання і спрямованість антирелігійної пропаганди щодо конкретного періоду;

- організаційні заходи, спрямовані на досягнення визначених завдань;

- форми і методи роботи з урахуванням заявлених цілей і особливостей етапів історичного періоду розвитку (Губанов, 1970 : 23-37) (напр., неп, індустріалізація, колективізація тощо).

Попри декларативність, чіткого усвідомлення змісту, форм i наповнюваності антирелігійної пропаганди на початку 1920-х (вірогідно, аж до середини десятиріччя) років партійно-державне керівництво не мало. Варто звернути увагу хоча б на вживання термінів «антирелігійна пропаганда», «антицерковна пропаганда», «боротьба 3 релігійними забобонами (атеїзм)» (Культурне будівництво, 1959 : 151) тощо. Подальшого вивчення потребує й питання періодизації розвитку антирелігійної пропаганди, хоча перші спроби в цьому напрямку були зроблені ще сучасниками в 20-30-ті роки минулого сторіччя (Ярославский Ем., 1929 : 4-7; Попов, 1930 : 58-61; Кефала, 1932 : 355369 та ін.). Фактично від початку 1920-х років маніфестування політичних цілей у галузі релігії та хаотичне втручання радянської адміністрації у церковні 


\section{справи поступово трансформувалося у широкомасштабний наступ влади на релігію та церкву.}

\section{СПИСОК ВИКОРИСТАНИХ ДЖЕРЕЛ І ЛІТЕРАТУРИ}

Аверинцев, 2004 - Аверинцев С. Софія - Логос. Словник. Вид. 2-е, випр. і доп. К.: Дух і літера, 2004 . Амосов, 1932 - Амосов Н. Антирелигиозное воспитание в действии // Воинствующее безбожие в СССР за 15 лет. 1917-1932. Москва : ОГИЗ-ГАИЗ, 1932. С. 285-286.

Бердяев, 1990 - Бердяев Н. Истоки и смысл русского коммунизма. Москва : Наука, 1990.

Воронцов, 1973 - Воронцов Г. В. Ленинская программа атеистического воспитания в действии (1917-1937 гг.). Л.: Изд-во Ленинград. ун-та, 1973.

Восьмий з 'їзд РКП(б), 1979 - Восьмий з’їзд РКП(б). Москва. 18-23 березня 1919 року. Резолюції і постанови 3'їзд: Програма Російської комуністичної партії (більшовиків) // Комуністична партія Радянського Союзу 8 резолющіях і рішеннях з їздів, конференцій і пленумів ЦК (1898-1970) / Переклад з восьмого рос. вид. К.: Вид-во політ. літ-ри України, 1979. Т. 2. 1917-1924.

Гірц, 2001 - Гірц К. Інтерпретація культур. К.: Дух і літера, 2001. С. 227-273.

Губанов, 1970 - Губанов Н. И. О понятии «система атеистического воспитания» // Вопросы научного атеизма. Вып. 9. М.: Мысль, 1970. С. 23-37.

ДАПО - Державний архів Полтавської області.

Дурдыневский, Берцианский, 1925 - Дурдыневский В., Берцианский С. Опыт библиографии общественных наук за революционное трехлетие (1918-1920 гг.). М.-Л., 1925.

Культурне будівництво, 1959 - Культурне будівництво в Українській РСР. Важливіші рішення Комуністичної партії і радянського уряду 1917-1959 рр. Зб. документів: В 2-х т. Т.1 (1917-червень 1941 рр.). К.: Держ. вид-во політ. літ-ри УРСР, 1959. С. 151.

Ленин - Ленин В.И. Полное собрание сочинений. Т. 50.

Луначарский, 1919 - Луначарский А.В. Об антирелигиозной пропаганде // Револющия и церковь. 1919 . № 1.

Лягушина, 1965 - Лягушина Э.Я. Борьба против антинародной деятельности Православной церкви в годы гражданской войны и интервенции (1918-1920). Автореф. дис. ... канд. ист. наук. М., 1965.

Народное просвещение, 1918 - Народное просвещение. 1918. № 19. С. 7.

Персиц, 1967 - Персиц М. М. Великая Октябрьская социалистическая революция и создание условий для распространения атеизма в массах // Вопросы научного атеизма. Вып. 4. М.: Мысль, 1967. С. 15-37.

Плаксин, 1968 - Плаксин Р. Ю. Крах церковной контрреволюции. 1917-1923 гг. М.: Наука, 1968. 192 с.;

Полєжаєв, 2015 - Полєжаєв Д. В. Ментальність особистості: філософсько-освітній аспект // Психологія $i$

особистість. 2015. № 2. Ч. 1. С. 71-85.

Попов, 1930 - Попов Ф. Первые годы безбожия // Антирелигиозник. 1930. №4. С. 58-61.

Рожицын, 1922 - Рожицын В. Антирелигиозная пропаганда // Антирелигиозная пропаганда: Сб. материалов. Харьков: Изд. ЦК КП(б)У, 1922.

Силантьев, 1998 - Силантьев В.И. Большевики и Православная церковь на Украине в 20-е годы. Харьков: Харьк. госуд. политехн. ун-т, 1998.

Хейер, 2002 - Хейер Э. Религиозный раскол в среде российских аристократов в 1860 - 1900 годы. Редстокизм и пашковщина / Пер. В.Сильчука. Москва : Изд-во. «Икар», 2002.

Ярославский, 1932 - Ярославский Ем. Борьба с религией в первые годы Октябрьской революции // Воинствующее безбожие в СССР за 15 лет. 1917-1932. Сб. под ред. М. Енишерлова, А. Лукачевского, М. Митина. М.: ОГИЗ-ГАИЗ, 1932. С. 323.

Ярославский, 1929 - Ярославский Ем. Развернутым фронтом. О задачах и методах антирелигиозной пропаганды. Доклад на II Всесоюзном съезде Союза безбожников. Москва.: Акц. Изд-во об-ва «Безбожник», 1929. С. 4-7.

ЦДАГО України - Центральний державний архів громадських об'єднань України.

Циркулярное письмо, 1922 - Циркулярное письмо ЦК КП(б)У №334. Всем Губкомам и всем членам партии // Антирелигиозная пропаганда. Сб. материалов. Харьков: Издание ЦК КП(б)У, 1922. С. 188-189;

Durkheim, 1968 - Durkheim E. Les formes elementaries de la vie religeuse, 5 eme edition, PUF-Paris, 1968. P. 3.

\section{REFERENCES}

Averyntsev, 2004 - Averyntsev S. Sofiia - Lohos. Slovnyk [Sofia - Logos. Dictionary]. Vyd. 2-e, vypr. i dop. K.: Dukh i litera, 2004 [in Ukrainian].

Amosov, 1932 - Amosov N. Antyrelyhyoznoe vospytanye v deistvyy [Anti-religious education in action] // Voynstvuiushchee bezbozhye v SSSR za 15 let. 1917-1932. Moskva : OHYZ-HAYZ, 1932. S. 285-286 [in Russian]. 
Berdiaev, 1990 - Berdiaev N. Ystoky y smыsl russkoho kommunyzma [The origins and meaning of Russian communism]. Moskva : Nauka, 1990 [in Russian].

Vorontsov, 1973 - Vorontsov H. V. Lenynskaia prohramma ateystycheskoho vospytanyia v deistvyy (1917-1937 hh.) [ Lenin's program of atheistic education in action (1917-1937)]. L.: Yzd-vo Lenynhrad. un-ta, 1973 [in Russian].

Vosmyi zizd RKP(b), 1979 - Vosmyi zizd RKP(b). Moskva. 18-23 bereznia 1919 roku. Rezoliutsii i postanovy zizdu: Prohrama Rosiiskoi komunistychnoi partii (bilshovykiv) [Eighth Congress of the RCP (b). Moscow. March 18-23, 1919. Resolutions and resolutions of the Congress: The program of the Russian Communist Party (Bolsheviks)] // Komunistychna partiia Radianskoho Soiuzu v rezoliutsiiakh i rishenniakh zizdiv, konferentsii i plenumiv TsK (18981970) / Pereklad z vosmoho ros. vyd. K.: Vyd-vo polit. lit-ry Ukrainy, 1979. T. 2. 1917-1924 [in Ukrainian].

Hirts, 2001 - Hirts K. Interpretatsiia kultur [Interpretation of cultures]. K.: Dukh i litera, 2001. S. 227-273 [in Ukrainian].

Hubanov, 1970 - Hubanov N. Y. O poniatyy «systema ateystycheskoho vospytanyia» [About the concept of "system of atheistic education"] // Voprosы nauchnoho ateyzma. Vыр. 9. M.: Mыsl, 1970. S. 23-37 [in Russian].

DAPO - Derzhavnyi arkhiv Poltavskoi oblasti [State Archives of Poltava region] [in Ukrainian].

Durdыnevskyi, Bertsyanskyi, 1925 - Durdыnevskyi V., Bertsyanskyi S. Opыt byblyohrafyy obshchestvennыkh nauk za revoliutsyonnoe trekhletye (1918-1920 hh.) [The experience of the bibliography of social sciences for the revolutionary three years (1918-1920)]. M.-L., 1925 [in Russian].

Kulturne budivnytstvo, 1959 - Kulturne budivnytstvo v Ukrainskii RSR. Vazhlyvishi rishennia Komunistychnoi partii i radianskoho uriadu 1917-1959 rr [Cultural construction in the Ukrainian SSR. The most important decisions of the Communist Party and the Soviet government of 1917-1959.]. Zb. dokumentiv: V 2-kh t. T.1 (1917-cherven 1941 rr.). K.: Derzh. vyd-vo polit. lit-ry URSR, 1959. S. 151 [in Ukrainian].

Lenyn - Lenyn V.Y. Polnoe sobranye sochynenyi [Full composition of writings]. T. 50 [in Russian].

Lunacharskyi, 1919 - Lunacharskyi A.V. Ob antyrelyhyoznoi propahande [On anti-religious propaganda] // Revoliutsyia y tserkov. 1919. № 1 [in Russian].

Liahushyna, 1965 - Liahushyna Э.Ia. Borba protyv antynarodnoi deiatelnosty Pravoslavnoi tserkvy v hodb hrazhdanskoi voinы y ynterventsyy (1918-1920) [Struggle against the anti-popular activities of the Orthodox Church during the years of civil war and intervention (1918-1920)]. Avtoref. dys. ... kand. yst. nauk. M., 1965 [in Russian].

Narodnoe prosveshchenye, 1918. - Narodnoe prosveshchenye [Public education]. 1918. № 19. S. 7 [in Russian].

Persyts, 1967 - Persyts M. M. Velykaia Oktiabrskaia sotsyalystycheskaia revoliutsyia y sozdanye uslovyi dlia rasprostranenyia ateyzma v massakh [The Great October Socialist Revolution and the Creation of Conditions for the Spread of Atheism among the Masses] // Voprosы nauchnoho ateyzma. Vыр. 4. M.: Mыsl, 1967. S. 15-37 [in Russian]. Plaksyn, 1968 - Plaksyn R. Yu. Krakh tserkovnoi kontrrevoliutsyy. 1917-1923 hh [The collapse of the church counterrevolution. 1917-1923 biennium]. M.: Nauka, 1968. 192 s. [in Russian]

Poliezhaiev, 2015 - Poliezhaiev D. V. Mentalnist osobystosti: filosofsko-osvitnii aspect [Personality mentality: philosophical and educational aspect] // Psykholohiia i osobystist. 2015. № 2. Ch. 1. S. 71-85 [in Ukrainian].

Popov, 1930 - Popov F. Pervыe hodы bezbozhyia [The first years of godlessness] // Antyrelyhyoznyk. 1930. №4. S. 58-61 [in Russian].

Rozhytsыn, 1922 - Rozhytsыn V. Antyrelyhyoznaia propahanda [Anti-religious propaganda] // Antyrelyhyoznaia propahanda: Sb. materyalov. Kharkov: Yzd. TsK KP(b)U, 1922 [in Russian].

Sylantev, 1998 - Sylantev V.Y. Bolshevyky y Pravoslavnaia tserkov na Ukrayne v 20-e hodы [The Bolsheviks and the Orthodox Church in Ukraine in the 1920s]. Kharkov: Khark. hosud. polytekhn. un-t, 1998 [in Russian].

Kheier, 2002 - Kheier Э. Relyhyoznыi raskol v srede rossyiskykh arystokratov v 1860 - 1900 hodы. Redstokyzm y pashkovshchyna [Religious schism among Russian aristocrats in 1860-1900. Redstockism and Pashkovism] / Per. V.Sylchuka. Moskva : Yzd-vo. «Ykar», 2002 [in Russian].

Yaroslavskyi, 1932 - Yaroslavskyi Em. Borba s relyhyei v pervыe hodы Oktiabrskoi revoliutsyy [The fight against religion in the early years of the October Revolution] // Voynstvuiushchee bezbozhye v SSSR za 15 let. 1917-1932. Sb. pod red. M. Enysherlova, A. Lukachevskoho, M. Mytyna. M.: OHYZ-HAYZ, 1932. S. 323 [in Russian].

Yaroslavskyi, 1929 - Yaroslavskyi Em. Razvernutыm frontom. O zadachakh y metodakh antyrelyhyoznoi propahandы. Doklad na II Vsesoiuznom sъezde Soiuza bezbozhnykov [A deployed front. On the tasks and methods of anti-religious propaganda. Report at the II All-Union Congress of the Union of Atheists]. Moskva.: Akts. Yzd-vo ob-va «Bezbozhnyk», 1929. S. 4-7 [in Russian].

TsDAHO Ukrainy - Tsentralnyi derzhavnyi arkhiv hromadskykh obiednan Ukrainy [Central State Archives of the Community of Ukraine] [in Ukrainian]. 
Tsyrkuliarnoe pysmo, 1922 - Tsyrkuliarnoe pysmo TsK KP(b)U №334. Vsem Hubkomam y vsem chlenam party [Circular letter of the CC CP (b) U No. 334. To all Gubkoms and all party members] // Antyrelyhyoznaia propahanda. Sb. materyalov. Kharkov: Yzdanye TsK KP(b)U, 1922. S. 188-189 [in Russian].

Durkheim, 1968 - Durkheim E. Les formes elementaries de la vie religeuse, 5 eme edition [Les formes elementaries de la vie religeuse, 5 eme edition], PUF-Paris, 1968. P. 3. [in French]. 